\title{
Molecular Analysis of Coxiella Burnetii by Isocitrate Dehydrogenase Gene Sequence-Based Typing and PCR- RFLP in Isfahan, Iran
}

\author{
Zary Nokhodian ${ }^{1}$, Mohammad Khalili ${ }^{2}$, Behrooz Ataei ${ }^{1}$, Awat Feizi ${ }^{3}$, Abdolreza Moradi ${ }^{4}$, Soodabeh Rostami ${ }^{5}$ \\ and Majid Yaran ${ }^{1}$
}

${ }^{I}$ Infectious Diseases and Tropical Medicine Research Center, Isfahan University of Medical Sciences, Isfahan, Iran ${ }^{2}$ Department of Pathobiology, School of Veterinary Medicine, Shahid Bahonar University of Kerman, Kerman, Iran ${ }^{3}$ Department of Biostatistics and Epidemiology, School of Health, Isfahan University of Medical Sciences, Isfahan, Iran ${ }^{4}$ Isfahan Veterinary Offices, Head of Public Health Supervision Section, Isfahan, Iran ${ }^{5}$ Nosocomial Infection Research Center, Isfahan University of Medical Sciences, Isfahan, Iran

*Corresponding author`s Email: srostami1876@gmail.com; ORCID: 0000-0002-9281-0398

\begin{abstract}
In the recent years, considerable advances have been made in the detection and genotyping of Coxiella burnetii, the causative agent of $\mathrm{Q}$ fever. The selection of appropriate genotyping method has enabled description of the clonal diversity of $C$. burnetii around the word. Since, in the place of study, C. burnetii genotyping has not been done, the icd gene Restriction fragment length polymorphism (RFLP) and sequence-based typing for differentiation between the genomic detected $C$. burnetii from the various sources and compared the two methods is used. In a observational study, a total of 15 genomic positive cases of $C$. burnetii infection from different sources in Isfahan province (Central Iran) were enrolled and underwent two genotyping methods: the icd gene PCR-RFLP and icd gene sequence-based typing. The degree of similarity between the $i c d$ gene sequences was high (98.3-100\%). In compare with $C$. burnetii Nine Mile icd gene sequence, the nucleotide sequences were different at 11 positions, which resulted in 7 differences in the amino acid sequences. After digesting the $370 \mathrm{bp}$ amplified icd gene fragments all the samples indicated only one band of 370bp, while amplified C. burnetii Nine Mile strain icd gene were digested into two bands with sizes of $221 \mathrm{bp}$ and $149 \mathrm{bp}$. The results of two genotyping methods matched together. Used methods in present study were cheaper and easier than new methods and they can used for detection of acute and chronic phases of infection.
\end{abstract}

Key words: Coxiella burnetii, Isocitrate dehydrogenase, Iran, Restriction fragment length polymorphism, Sequencebased typing

\section{INTRODUCTION}

Coxiella burnetii, the causative agent of $\mathrm{Q}$ fever in humans and animals, is a gram negative highly infectious coccobacillus, with an infectious dose of less than ten organisms (Massung et al., 2012). This bacterium has been found in all parts of the world except New Zealand and Antarctica (Sidi-Boumedine and Rousset, 2011; Prevention, 2013). The main reservoirs of human infection are ruminant such as cattle, goats and sheep (Capin et al., 2013). Humans are accidentally infected by $C$. burnetii. A common rout of transmission of $C$. burnetii to humans occurs through inhalation of contaminated aerosols arising from the infected animal body fluids. However, human infection has also occurred via the following ways: placental transmission to the fetus (Raoult and Stein 1994), blood transfusions (Pantanowitz et al., 2002) and consumption of raw milk (Signs et al., 2012). C. burnetii is also a potential bioterrorism agent and belongs to the category B of CDC -list (Massung et al., 2012). In human Q fever presents in two forms: acute and chronic. Acute disease often manifests as self-limiting febrile flu-like illness, pneumonia and hepatitis (Prevention, 2013). Whereas, chronic Q fever is a serious condition that present in forms of endocarditis, vascular infections and bone and joint infections (Million and Raoult, 2015). Even Q fever infection was seen as coinfection inside Scrub Typhus (Jeong et al., 2019).

Because $\mathrm{Q}$ fever is considered as a zoonotic disease, the human infection epidemiology relates to the circulation of the bacterium in animal reservoirs (Eldin et al., 2017). On the other hand, differentiation between the $C$. burnetii isolates is important in diagnostic and epidemiological research, due to the vast extent of Q fever infection and multiple hosts of C. burnetii. Genotyping can be a key tool for understanding and follow up the epidemiology of the $\mathrm{Q}$ fever and by using that it can be find the animal source of human infection (Eldin et al., 2017). Furthermore, in a study by Van Nguyen et al. 
(1999) was suggested that the differences at the molecular level between the strains of $C$. burnetii may be responsible for acute or chronic forms of Q fever (Van Nguyen and Hirai, 1999). The C. burnetii icd gene encoding isocitrate dehydrogenase is an acid-induced and housekeeping gene that may be associated with the ability of the bacterium to replicate in the acidic environment of the phagolysosomes (Van Nguyen and Hirai, 1999; Van Nguyen et al., 1999).

Several genotyping methods have been developed for differentiating C. burnetii isolates. One of these techniques is Restriction fragment length polymorphism (RFLP) analysis of genomic DNA and PCR-RFLP of specific genes (Eldin, et al., 2017). In the present study, we used the icd gene PCR-RFLP and sequence-based typing for differentiation between the genomic detected $C$. burnetii from the various sources. In addition, in this survey we compared the obtained icd gene sequences with some $C$. burnetii strains icd gene sequences submitted in GenBank and we found the relationship between the isolates based on the icd gene sequence.

\section{MATRIALS AND METHODS}

\section{Ethical approval}

Written informed consent was obtained from all individuals and farm owners and the study protocol was approved by the ethics committee of Isfahan University of medical sciences (No. 194033).

\section{Bacteria}

In a series of cross-sectional studies conducted by Isfahan Infectious Diseases and Tropical Medicine Research Center (Grant No. 293390 to 293393) on May to June 2015 in Isfahan province, Iran, 34 genomic positive cases of $C$. burnetii infection from different sources (Human whole blood, animal whole blood including: Sheep and Cow and Bulk Tank Milk (BTM) from dairy Cows) were detected. The present study was performed in the following of the mentioned studies with grant no. 194033. We randomly selected 15 cases from 34 positive cases that the original sources and other characteristics of them are shown in table 1.

\section{C. burnetii icd gene nested PCR}

Bacterial DNA was extracted from human and animal (Sheep and Cow) whole blood and BTM from dairy cows samples using the YTA Genomic DNA Extraction mini kit (Yekta Tajhiz Azma Co., Tehran., Iran) according to the manufacturer's instructions. Oligonucleotide primers used in this survey are presented in Table 2. First of all, we amplified a $400 \mathrm{bp}$ fragment using $i c d 1-\mathrm{F}$ and $i c d 2-\mathrm{R}$ primers and then a $370 \mathrm{bp}$ fragment using $i c d N-\mathrm{F}$ and $i c d N-\mathrm{R}$ primers (Van Nguyen and Hirai, 1999). PCR reaction was performed in a $25 \mu 1$ mixture containing: $1 X$ PCR buffer, 1.5 $\mathrm{mM} \mathrm{MgCl} 2,200 \mathrm{mM}$ of each deoxynucleotide triphosphate (dNTP), $1 \mathrm{U}$ of Taq DNA polymerase (SinaClon Bioscience Co., Tehran., Iran), $0.2 \mathrm{mM}$ of each primer (Bioneer Co., Daejeon., Korea) and $5 \mu$ l genomic DNA for first step of PCR and $1 \mu \mathrm{l}$ PCR product for second step of PCR. PCR conditions were programmed in T100 ${ }^{\mathrm{TM}}$ Thermal Cycler (Bio-Rad, USA) for both steps as follows: Initial denaturation at $94^{\circ} \mathrm{C}$ for $3 \mathrm{~min}$; followed by 35 cycles at $94^{\circ} \mathrm{C}$ for $60 \mathrm{~s}, 58^{\circ} \mathrm{C}$ for $45 \mathrm{~s}$ and $72^{\circ} \mathrm{C}$ for $45 \mathrm{~s}$ and final extension at $72^{\circ} \mathrm{C}$ for $10 \mathrm{~min}$. PCR products of second step were separated with electrophoresis on $2 \%$ agarose gel (SinaClon Bioscience Co., Tehran., Iran) and after staining with ethidium bromide, visualized under UV gel documentation system. Genomic DNA of C. burnetii Nine Mile strain was used as a positive control.

\section{Sequencing of the icd gene fragments}

For DNA sequencing, amplified products of second step of PCR underwent bidirectional Sanger sequencing using the ABI 3730 XL DNA analyzer (Applied Biosystems, USA) by Bioneer Co., Korea. The obtained sequences were blasted against the nucleotide database of the National Center for Biotechnology Information (NCBI, 2019). Then, the obtained sequences were aligned against the icd gene sequences of $C$. burnetii Nine Mile and 5 other $C$. burnetii strains using the Clustal W v2.0 software. The icd gene sequences accession numbers of used $C$. burnetii strains are as follows: AF069035 (Nine Mile, Type strain for acute Q fever), AF146291 (Bangui strain isolated from acute Q fever), AF146285 (TK-1 strain isolated from acute Q fever), AF146294 (Priscilla, Type strain for chronic Q fever), NC_011527.1 (CbuG_Q212 strain isolated from chronic Q fever) and CP001020.1 (CbuK_Q154 strain isolated from chronic Q fever). Phylogenetic tree was constructed by MEGA Version 6.0 (Koichiro Tamura, 2013) and Neighbor-Joining method (Saitou and Nei, 1987).

\section{PCR-restriction fragment length polymorphism (PCR-RFLP) analysis}

The icd gene nested-PCR products were digested with the FastDigest Bsh1236 I restriction enzyme (Thermofisher Scientific., USA) as described by the manufactures. This enzyme recognizes CG $\downarrow$ CG site. Briefly, in a $30 \mu l$ reaction containing: $2 \mu \mathrm{L}$ of appropriate $10 \mathrm{X}$ buffer, $1 \mu \mathrm{L}$ of $B$ sh1236 I enzyme and $17 \mu \mathrm{L}$ distilled water, $10 \mu \mathrm{L}$ of PCR products was added and incubated at $37^{\circ} \mathrm{C}$ for 5 minutes. Then, microtubes were incubated at $80^{\circ} \mathrm{C}$ for 10 minutes to deactivate 
the enzyme. Digested products were separated by electrophoresis on $2 \%$ agarose gel containing $0.1 \mu 1 / \mathrm{ml}$ ethidium bromide and were visualized using an UV gel documentation system. Genomic DNA of C. burnetii Nine Mile strain was used as the control.

Table 1. Characteristics of the evaluated genomic positive cases of $C$. burnetii in this study

\begin{tabular}{|c|c|c|c|c|c|c|}
\hline Samples & Characteristics & & & & & \\
\hline $\begin{array}{l}\text { Origin: } \\
\text { Human }\end{array}$ & $\begin{array}{l}\text { Age } \\
\text { (years) }\end{array}$ & Sex & Occupation & $\begin{array}{l}\text { Length of } \\
\text { employment } \\
\text { (years) }\end{array}$ & \multicolumn{2}{|c|}{$\begin{array}{l}\text { Consumption of unpasteurized } \\
\text { milk }\end{array}$} \\
\hline $\mathrm{CH} 3$ & 30 & Male & Butcher & 9 & \multicolumn{2}{|l|}{ No } \\
\hline DH4 & 43 & Male & Farmer & 15 & \multicolumn{2}{|l|}{ Yes } \\
\hline EH5 & 48 & Male & Slaughterer & 30 & \multicolumn{2}{|l|}{ Yes } \\
\hline $\begin{array}{l}\text { Origin: } \\
\text { BTM }\end{array}$ & $\begin{array}{l}\text { Reproductive } \\
\text { disorders in the } \\
\text { herd }\end{array}$ & $\begin{array}{l}\text { Types of } \\
\text { cattle herds }\end{array}$ & $\begin{array}{l}\text { Contact } \\
\text { With other } \\
\text { ruminant species }\end{array}$ & \multicolumn{3}{|c|}{ Contamination with ticks in the herd } \\
\hline AM1 & No & Traditional & No & \multicolumn{3}{|l|}{ No } \\
\hline IM9 & Yes & Traditional & No & \multicolumn{3}{|l|}{ No } \\
\hline TM20 & Yes & Traditional & Yes & \multicolumn{3}{|l|}{ No } \\
\hline VM22 & No & Traditional & No & \multicolumn{3}{|l|}{ No } \\
\hline WM23 & No & Commercial & No & \multicolumn{3}{|l|}{ No } \\
\hline XM24 & No & Traditional & No & \multicolumn{3}{|l|}{ No } \\
\hline $\begin{array}{l}\text { Origin: } \\
\text { Ruminants }\end{array}$ & Type & Age (mounts) & Sex & Strain & $\begin{array}{l}\text { Reproductive } \\
\text { disorders }\end{array}$ & $\begin{array}{l}\text { Contamination } \\
\text { with ticks }\end{array}$ \\
\hline FA6 & Sheep & 36 & Female & Mixed & No & Yes \\
\hline GA7 & Sheep & 40 & Male & Afshari & No & No \\
\hline HA8 & Cow & 54 & Female & $\begin{array}{l}\text { Holstein } \\
\text { Friesians }\end{array}$ & No & No \\
\hline JA10 & Cow & 50 & Female & $\begin{array}{l}\text { Holstein } \\
\text { Friesians }\end{array}$ & No & No \\
\hline RA18 & Sheep & 40 & Female & Afshari & No & No \\
\hline
\end{tabular}

Table 2. Primers sequences used in the study

\begin{tabular}{|c|c|c|c|}
\hline Name of primers & Sequences $\left(5^{\prime}-3^{\prime}\right)$ & Amplicon size & References \\
\hline icd1-F & CGGAGTCTCTTAGTGATGACGGA & \multirow{2}{*}{$400 \mathrm{bp}$} & \multirow{4}{*}{$\begin{array}{c}\text { (Van Nguyen and } \\
\text { Hirai, 1999) }\end{array}$} \\
\hline icd2-R & GCCTTCTTTAGAAACCGGTTTAA & & \\
\hline$i c d \mathrm{~N}-\mathrm{F}$ & GGAGTTAACCGGAGTATCCA & \multirow{2}{*}{$370 \mathrm{bp}$} & \\
\hline$i c d \mathbf{N}-\mathbf{R}$ & ATTGAGCGAACGTATGCCAC & & \\
\hline
\end{tabular}

\section{RESULTS}

Fifteen obtained partial icd gene sequences were aligned and compared with six $C$. burnetii icd gene sequences derived from GeneBank. The degree of similarity between the nucleotide sequences of present study was high (98.3-100\%). In compare with $C$. burnetii Nine Mile icd gene sequence (GenBank accession No.: AF069035.1), presentnucleotide sequences were different at 11 positions, which resulted in seven differences in the amino acid sequences (Table 3 ). Point mutation was the cause of all changes and other type of mutations were not seen. Among our sequences there was a common mutation at position 745 according to the $C$. burnetii Nine Mile icd gene sequence. In six samples just one point mutation $(745 \mathrm{G} \rightarrow \mathrm{A})$ were seen. However, in seven samples were seen two different point mutations and in other two samples were observed three other point mutations. Figure 1 showed the phylogenetic tree constructed based on the icd gene sequences obtained in this study and C. burnetii icd gene sequences from six mentioned strains.

After digesting the 370 bp C. burnetii Nine Mile strain icd gene amplified with primers icd N-F and icd N-R, two bands were produced with size of $221 \mathrm{bp}$ and $149 \mathrm{bp}$ on the agarose gel. In contrast, amplified fragments from all the samples indicated only one band of 370bp. Numbers of the PCR-RFLP patterns of C. burnetii samples are presented in figure 2 . 
Table 3. observed mutations in the samples compared with C. burnetii Nine Mile strain

\begin{tabular}{|c|c|c|c|}
\hline \multirow{2}{*}{ Sample No. } & \multicolumn{2}{|c|}{ Mutations } & \multirow{2}{*}{$\begin{array}{l}\text { Gene Bank } \\
\text { accession no. }\end{array}$} \\
\hline & Nucleotide changes & Amino acid changes & \\
\hline AM1 & $745 \mathrm{G} \rightarrow \mathrm{A}$ & Ala53 $\rightarrow$ Thr & KY962668.1 \\
\hline CH3 & $745 \mathrm{G} \rightarrow \mathrm{A} / 866 \mathrm{~A} \rightarrow \mathrm{G}$ & Ala53 $\rightarrow$ Thr $/$ Asp93 $\rightarrow$ Ser & KY962669.1 \\
\hline DH4 & $745 \mathrm{G} \rightarrow \mathrm{A} / 800 \mathrm{~A} \rightarrow \mathrm{G}$ & Ala53 $\rightarrow$ Thr $/$ Lys $71 \rightarrow$ Arg & KY962670.1 \\
\hline EH5 & $745 \mathrm{G} \rightarrow \mathrm{A} / 690 \mathrm{~T} \rightarrow \mathrm{A} / 861 \mathrm{~A} \rightarrow \mathrm{G}$ & Ala53 $\rightarrow$ Thr & KY962671.1 \\
\hline FA6 & $745 \mathrm{G} \rightarrow \mathrm{A} / 883 \mathrm{~A} \rightarrow \mathrm{T}$ & Ala53 $\rightarrow \mathrm{Thr} / \mathrm{Thr} 99 \rightarrow$ Ser & KY962672.1 \\
\hline GA7 & $745 \mathrm{G} \rightarrow \mathrm{A}$ & Ala53 $\rightarrow$ Thr & KY962673.1 \\
\hline HA8 & $745 \mathrm{G} \rightarrow \mathrm{A} / 811 \mathrm{G} \rightarrow \mathrm{A}$ & Ala53 $\rightarrow$ Thr $/$ Glu $75 \rightarrow$ Lys & KY962674.1 \\
\hline IM9 & $745 \mathrm{G} \rightarrow \mathrm{A} / 849 \mathrm{~A} \rightarrow \mathrm{T}$ & Ala53 $\rightarrow$ Thr & KY962675.1 \\
\hline JA10 & $745 \mathrm{G} \rightarrow \mathrm{A}$ & Ala53 $\rightarrow$ Thr $/$ Lys87 $\rightarrow$ Asp & KY962680.1 \\
\hline RA18 & $745 \mathrm{G} \rightarrow \mathrm{A} / 934 \mathrm{~A} \rightarrow \mathrm{C}$ & Ala53 $\rightarrow \mathrm{Thr}$ & KY962681.1 \\
\hline VM22 & $745 \mathrm{G} \rightarrow \mathrm{A}$ & Ala53 $\rightarrow$ Thr & KY962676.1 \\
\hline WM23 & $745 \mathrm{G} \rightarrow \mathrm{A} / 750 \mathrm{C} \rightarrow \mathrm{T}$ & Ala53 $\rightarrow$ Thr & KY962677.1 \\
\hline XM24 & $745 \mathrm{G} \rightarrow \mathrm{A} / 866 \mathrm{~A} \rightarrow \mathrm{G} / 902 \mathrm{~A} \rightarrow \mathrm{G}$ & Ala53 $\rightarrow$ Thr $/$ Asp93 $\rightarrow$ Ser/Glu105 $\rightarrow$ Gly & KY962678.1 \\
\hline ZA25 & $745 \mathrm{G} \rightarrow \mathrm{A}$ & Ala53 $\rightarrow$ Thr & KY962679.1 \\
\hline TM20 & $745 \mathrm{G} \rightarrow \mathrm{A}$ & Ala53 $\rightarrow$ Thr & KY962682.1 \\
\hline
\end{tabular}

No: Number

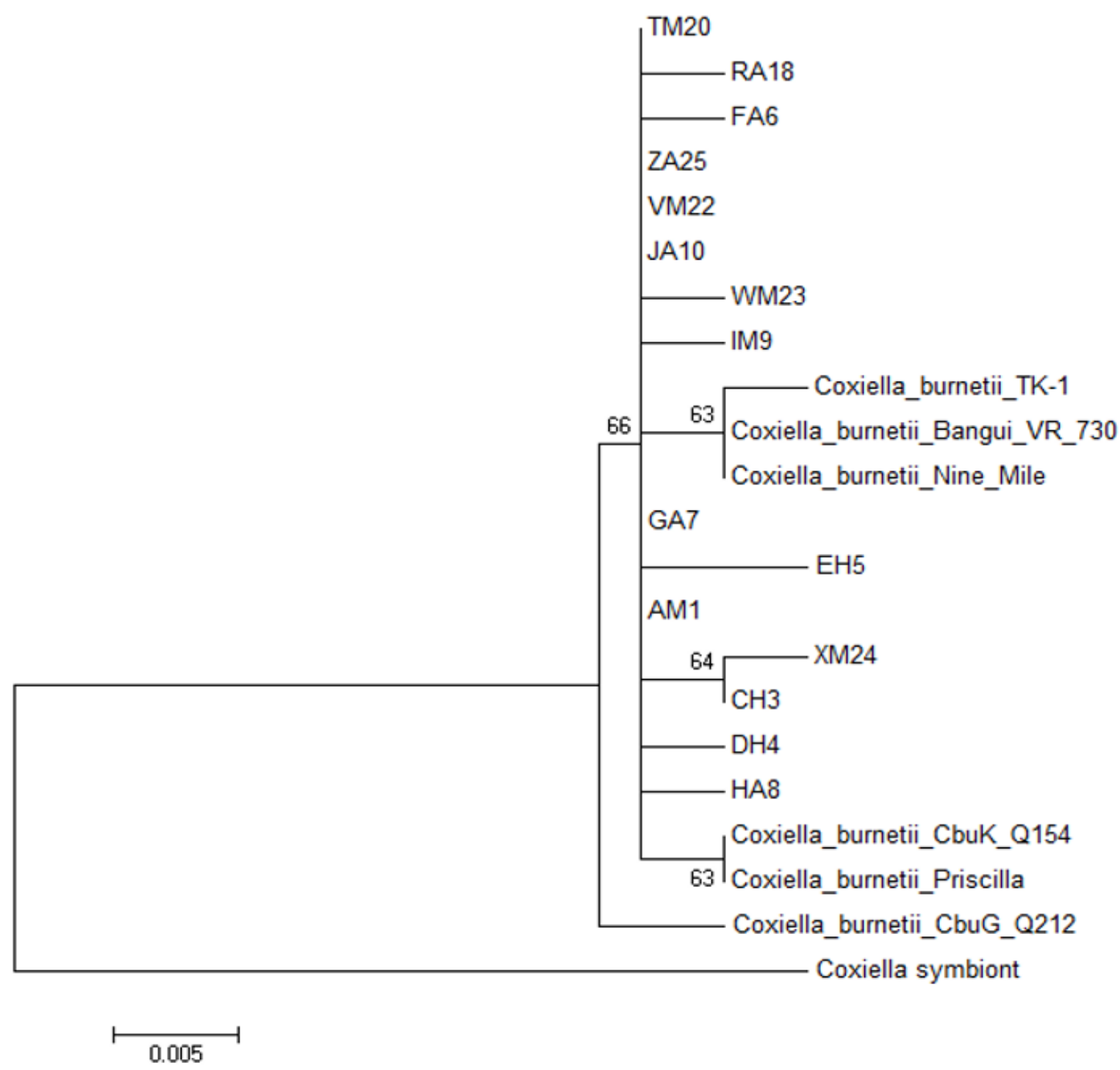

Figure 1. Phylogenetic tree constructed based on the icd gene sequences. The phylogenetic tree was inferred using the Neighbor-Joining method. The evolutionary distances were computed using the $\mathrm{p}$-distance method and were in the units of the number of base differences per site. The tree was rooted using $C$. symbiont as the out group. The support of each branch, as determined from 1000 bootstrap samples, is indicated by percentages at each nods. 


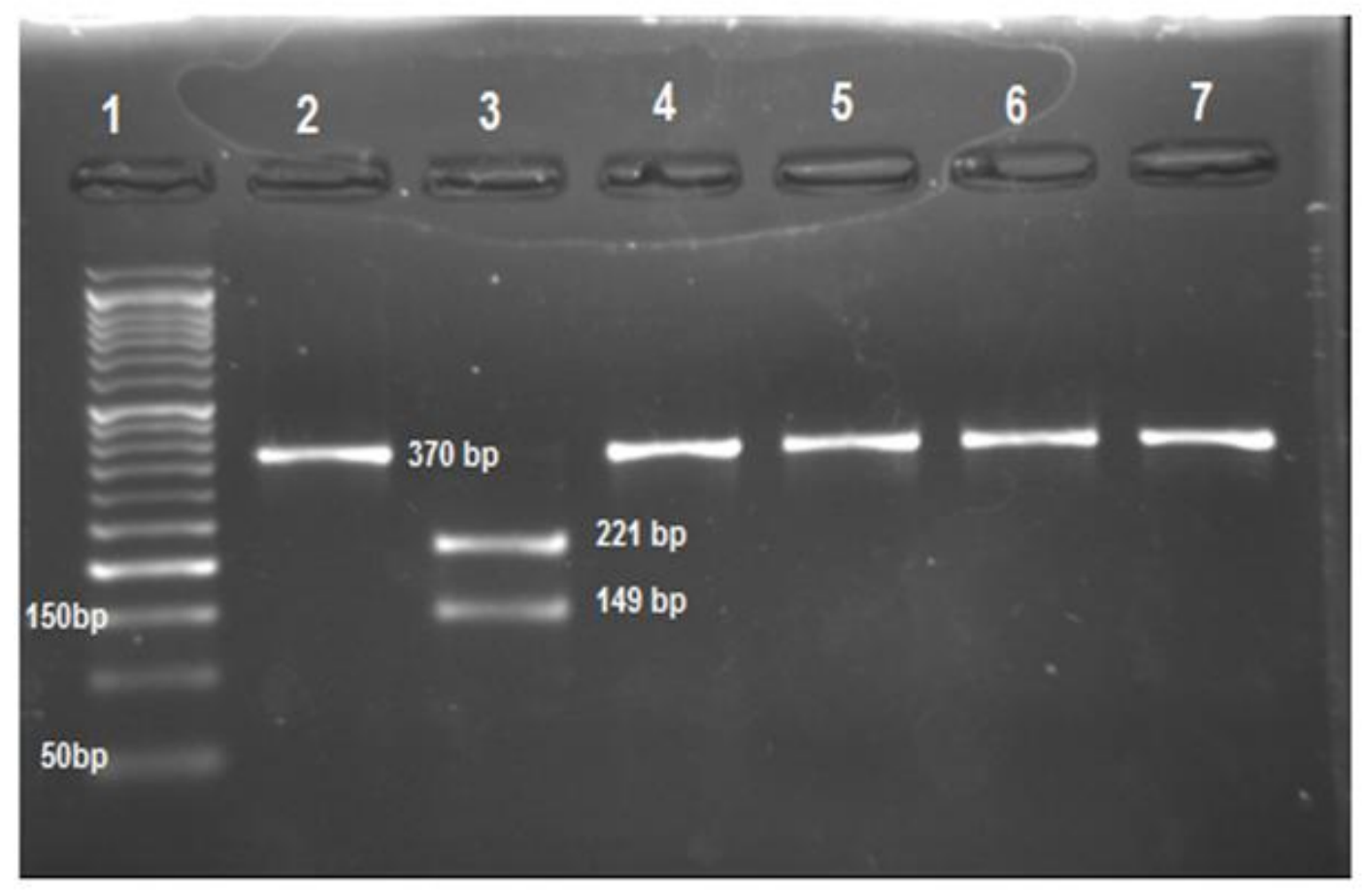

Figure 2. PCR-RFLP patterns of the icd gene from numbers of $C$. burnetii samples. Lanes: 1, 50bp DNA ladder; 2 , undigested nested-PCR product from C. burnetii Nine Mile strain; 3, Bsh1236 I -digested nested-PCR products of C. burnetii Nine Mile strain; 4-7, Bsh1236 I -digested nested-PCR products of samples

\section{DISCUSSION}

In the recent years, the different epidemiological profile of $C$. burnetii infections was reported in Iran. In the seroprevalence studies Q fever infection rates varied from $7.8 \%$ to $68 \%$ in the different sources (animals and high-risk population) (Khalili and Sakhaee, 2009; Aflatoonian et al., 2014; Azizzadeh et al., 2014; Esmaeili et al., 2014; Esmaeili et al., 2017, Khalili et al., 2014; Nokhodian et al., 2017). In the molecular studies the prevalence rate of C. burnetii DNA was reported from $0 \%$ to $48.15 \%$ in various samples (animals, human and ticks) by amplification of different genes included IS1111, 16S rRNA and Coml (Rahimi et al., 2010; Dehkordi 2011; Jamshidi et al., 2014; Khademi et al., 2014; Nokhodian et al., 2016). Unfortunately, until now, genotyping studies have not been done in Iran and according to the relative high prevalence of $C$. burnetii infection in this area, because of tremendous importance, to find the relationship between the isolates and the sources of the infection. In this study, for the first time in Iran, the number of isolates with the type strains of $C$. burnetii using the two simple and fast genotyping methods were compared. Based on the sequencing, it found that all the isolates had a common point mutation at nucleotide position 745 in the icd gene fragments. This point mutation also was seen in icd gene sequences of Priscilla (Type strain for chronic Q fever), CbuG_Q212 and CbuK_Q154 strains that isolated from chronic Q fever. However, this point mutation was not seen in icd gene sequences of Nine Mile strain (Type strain for acute Q fever), Bangui and TK-1 strains that isolated from acute $\mathrm{Q}$ fever.

On the other hand, in the Nine Mile strain icd gene amplified sequence there is one restriction site for Bsh1236 I restriction enzyme (position 744 to 747) and as it revealed in figure 2; Nine Mile strain nested-PCR product digested and two band were observed in agarose gel. However, none of samples were digested by restriction enzyme, so only one band was observed. Since the common point mutation in the isolates located at nucleotide position 745 and this site is located in restriction site, the results of both methods are consistent. Van Nguyan and Hirai (1999) studied the icd gene profile of 19 C. burnetii isolates. Based on the gene sequences, they divided the isolates into three groups included one group originated from acute $\mathrm{Q}$ fever and two groups originated from chronic $\mathrm{Q}$ fever. Similar to the results they found a common point mutation at position 745 in isolates originated from chronic Q fever (Van Nguyen and Hirai, 1999). In another study by Ando et al., using icd gene PCR-RFLP and sequencing analysis, 49 of 72 isolates had a completely identical nucleotide sequences and these isolates, same as 6 the isolates, had only one point mutation in position 745 $(\mathrm{G} \rightarrow \mathrm{A})$. They called these isolates "Japanese-specific" isolates and they claimed that the icd sequences of these isolates were not similar to other chronic C. burnetii strains (Andoh et al., 2004). However, in this study, all 6 identical nucleotide sequences were same as the chronic isolates submitted in GeneBank. Unfortunately, in the present study, no records about the clinical manifestation have seen (acute or chronic) of sources of isolates. However, according to these 
results, the isolates could be originated from the chronic or persistent focalized infections.Evaluating more $C$. burnetii isolates from different geographical area of Iran along with complete clinical information using these two methods is recommended in resent study. According to the primary studies, the initial steps of Citric Acid Cycle (CAC) pathway revealed the least conservation and changes in the genes encoding initial enzymes can effective on bacterial adaptations to different environments (Huynen et al., 1999). Since the isocitrate dehydrogenase enzyme is a member of the initial steps of CAC enzymes, mutations in the icd gene may be related to the $C$. burnetii pathogenicity and virulence. Therefore, it is suggestted more attention and study on the role of the isocitrate dehydrogenase enzyme in the different $C$. burnetii strains in the various environments.

Currently, the new genotyping methods were developed such as multiple-locus variable-number tandem repeat (VNTR) analysis (MLVA), Multi-spacer Sequence Typing (MST), and Single Nucleotide Polymorphism (SNP) genotyping (Eldin et al., 2017). Since it is better to determine the phase of the disease (Acute or chronic infection) and type of the genotype of the bacterium in the epidemiological studies and to decide for treatment of the infection, so use of the RFLP method, that is cheaper and easier than sequenced-based methods, can be helpful.

\section{DECLARATION}

\section{Acknowledgements}

This work was supported by the deputy vice-chancellor for research affairs of Isfahan University of Medical Sciences (grant numbers 194033). We would like to thank the Infectious Diseases and Tropical Medicine Research Center laboratory staff for supporting the practical work.

\section{Competing interests}

All authors have no conflict of interest.

\section{Consent to publish}

All authors gave their informed consent prior to their inclusion in the study.

\section{Authors' contributions}

ZN, MK, BA and AF conceived and designed the project. ZN, MK and SR Managed activities to annotate (produce metadata), scrub data and maintain research data for initial use and later re-use. MY Verified whether as a part of the activity or separate, of the overall replication of results and other research outputs. All authors interpreted the data, critically revised the manuscript for important intellectual contents and approved the final version.

\section{REFERENCES}

Aflatoonian MR, Khalili M, Sami M and Abiri Z (2014). The frequency of IgM anti-Coxiella burnetii (Q fever) antibodies among slaughterhouse workers in kerman city, 2012. Journal of Kerman University of Medical Sciences, 21 (5): 368-375.

Andoh M, Nagaoka H, Yamaguchi T, Fukushi H and Hirai K (2004). Comparison of japanese isolates of Coxiella burnetii by PCRRFLP and sequence analysis. Microbiology and immunology, 48 (12): 971-975. PMID: 15611614

Azizzadeh M, Taghavi Razavizadeh SAR and Mehrzad J (2014). Seroepidemiology of coxiellosis (Q fever) in sheep and goat populations in the northeast of iran. Iranian Journal of Veterinary Research, 15(1):1-6.

Capin GA, Emre Z, Canpolat S, Vatansever Y and Duzgun A (2013). Detection of Coxiella burnetii from ticks by polymerase chain reaction and restriction fragment length polymorphism. Ankara Üniversitesi Veteriner Fakültesi Dergisi, 2013;60:263-268.

Dehkordi FS (2011). Prevalence study of Coxiella burnetii in aborted ovine and caprine fetuses by evaluation of nested and real-time PCR assays. American Journal of Animal and Veterinary Sciences, 6:180-186. DOI:https://doi.org/10.3844/ajavsp.2011.180.186

Eldin C, Mélenotte C, Mediannikov O, Ghigo E, Million M, Mege JL, Maurin M and Raoult D (2017). From Q fever to Coxiella burnetii infection: A paradigm change. Clinical Microbiology Reviews, 30 (1): 115-190. DOI:https://doi.org/10.1128/CMR.00045-16

Esmaeili S, Golzar F, Ayubi E , Naghili B and Mostafavi E (2017). Acute Q fever in febrile patients in northwestern of Iran. PLOS Neglected Tropical Diseases, 11(4):e0005535. DOI:http://doi.org/10.1371/journal.pntd.0005535

Esmaeili S, Bagheri Amiri F and Mostafavi E (2014). Seroprevalence survey of Q fever among sheep in northwestern iran. VectorBorne and Zoonotic Diseases, 14 (3): 189-192. DOI: https://doi.org/10.1089/vbz.2013.1382

Huynen MA, Dandekar T and Bork P (1999). Variation and evolution of the citric-acid cycle: A genomic perspective. Trends in Microbiology, 7 (7): 281-291. PMID: 10390638

Jamshidi A, Razmyar J and Borji S (2014). Identification of Coxiella burnetii by touch-down PCR assay in unpasteurized milk and dairy products in north-east of iran. Iranian Journal of Veterinary Medicine, 8 (1): 15-19. 
Jeong HJ, Choi S, Lee J, Gill B, Lee KM, Lee YS, Kim CM, Yun NR and Kim DM (2019). Case Report: Scrub Typhus and Q Fever Coinfection. American Journal of Tropical Medicine and Hygiene, ahead of print. DOI:https://doi.org/10.4269/ajtmh.18-0092

Khademi P, Mahzounieh MR, Kahrizsangi AE and Shdravan E (2014). Genomic detection of Coxiella burnetii in goat milk samples in animal farms khorramabad township, iran. Pajoohandeh Journal, 19 (3): 162-168.

Khalili M, Mosavi M, Diali HG and Mirza HN (2014). Serologic survey for Coxiella burnetii phase II antibodies among slaughterhouse workers in kerman, southeast of iran. Asian Pacific Journal of Tropical Biomedicine, 4 (Suppl 1): S209-212. DOI:https://doi.org/10.12980/APJTB.4.2014C1268

Khalili M and Sakhaee E (2009). An update on a serologic survey of Qfever in domestic animals in iran. American Journal of Tropical Medicine and Hygiene, 80 (6): 1031-1032. PMID: 19478271

Koichiro T, Stecher G, Peterson D, Filipski A and Kumar S (2013). Mega6: Molecular evolutionary genetics analysis version 6.0. Molecular Biology and Evolution, 30 (12): 5. DOI:https://doi.org/10.1093/molbev/mst197

Massung RF, Cutler SJ and Frangoulidis D (2012). Molecular typing of Coxiella burnetii (Q fever). Advances in Experimental Medicine and Biology, 984: 381-396. DOI:https://doi.org/10.1007/978-94-007-4315-1_19

Million M and Raoult D (2015). Recent advances in the study of Q fever epidemiology, diagnosis and management. Journal of Infectio, 71 Suppl 1: S2-9. DOI:https://doi.org/10.1016/j.jinf.2015.04.024

National Center for Biotechnology Information (NCBI) (2019). availabe at http://www.ncbi.nlm.nih.gov/BLAST

Nokhodian Z, Ataei B, Moradi A, Yaran M, Hoseini SG, Feizi A and Sherkat R (2017). Seroprevalence and risk factors of Coxiella burnetii infection among high-risk population in center of iran, a neglected health problem. Acta Tropica, 169: 107-111. DOI:https://doi.org/10.1016/j.actatropica.2017.02.002

Nokhodian Z, Feizi A, Moradi A, Yaran M, Hoseini SG, Ataei B and Hosseini M (2016). Detection and risk factors of Coxiella burnetii infection in dairy cattle based on bulk tank milk samples in center of iran. Preventive Veterinary Medicine, 134: 139144. DOI:https://doi.org/10.1016/j.prevetmed.2016.10.003

Pantanowitz L, Telford SR and Cannon ME (2002). Tick-borne diseases in transfusion medicine. Transfusion Medicine, 12 (2): 85 106. PMID: 11982962

Anderson A, Bijlmer H, Fournier PE, Graves S, Hartzell J and Kersh GJ (2013). Diagnosis and management of q fever - united states, 2013: Recommendations from cdc and the q fever working group. Morbidity and mortality weekly report, 62 (3): 32. PMID: 23535757

Rahimi E, Doosti A, Ameri M, Kabiri E and Sharifian B (2010). Detection of Coxiella burnetii by nested pcr in bulk milk samples from dairy bovine, ovine, and caprine herds in iran. Zoonoses and public health, 57 (7-8): e38-e41. DOI:https://doi.org/10.1111/j.1863-2378.2009.01289.x

Raoult D and Stein A (1994). Q fever during pregnancy -- a risk for women, fetuses, and obstetricians. New England Journal of Medicine, 330 (5): 371-371. DOI: https://doi.org/10.1056/NEJM199402033300519

Saitou N and Nei M (1987). The neighbor-joining method: A new method for reconstructing phylogenetic trees. Molecular Biology and Evolution, 4 (4): 406-425. DOI: https://doi.org/10.1093/oxfordjournals.molbev.a040454

Sidi-Boumedine K and Rousset E (2011). Molecular epidemiology of q fever: A review of Coxiella burnetii genotyping methods and main achievements.

Signs KA, Stobierski MG and Gandhi TN (2012). Q fever cluster among raw milk drinkers in michigan, 2011. Clinical Infectious Diseases, 55 (10): 1387-1389. DOI: https://doi.org/10.1093/cid/cis690

Van Nguyen S and Hirai K (1999). Differentiation of Coxiella burnetii isolates by sequence determination and PCR-restriction fragment length polymorphism analysis of isocitrate dehydrogenase gene. FEMS Microbiology Letter, 180 (2): $249-254$. DOI:https://doi.org/10.1111/j.1574-6968.1999.tb08803.x

Van Nguyen S, To H, Yamaguchi T, Fukushi H and Hirai K (1999). Molecular cloning of an immunogenic and acid-induced isocitrate dehydrogenase gene from Coxiella burnetii. FEMS Microbiololgy Letter, 175 (1): 101-106. DOI:https://doi.org/10.1111/j.15746968.1999.tb13607.x 